Proc. Indian Acad. Sci. (Earth Planet. Sci.) Vol. 98, No. 2, July 1989, pp. 147-165.

(C) Printed in India.

\title{
Magnetotelluric survey across Singhbhum granite batholith
}

\author{
K K ROY, C K RAO and A CHATTOPADHYAY \\ Department of Geology and Geophysics, Indian Institute of Technology, Kharagpur 721 302, \\ India \\ MS received 22 September 1988; revised 13 March 1989
}

\begin{abstract}
Magnetotelluric soundings have been carried out across the archaean terrain of Singhbhum granite batholith from Bangriposhi to Keonjhar for a distance of about $100 \mathrm{~km}$. One-dimensional inversion models reveal that the depth of the moho varied between 23 and $40 \mathrm{~km}$. The depth of the lithosphere asthenosphere boundary varied from 58 to $76 \mathrm{~km}$. A zone of higher electrical conductivity detected at the base of the lower crust just above the moho is present along the entire profile. Signals within the range of 0.25 to 600 seconds, which crossed the coherency threshold of $0-8$ to 0.9 , could be stacked. Resistivity ranges of the crust mantle silicates below Singhbhum granite batholith vary over a wide range. Resistivity ranges are (i) $30,000-80,000 \mathrm{ohm}$ for Singhbhum granite phase II, (ii) 2,000 to 9,000 ohm-m for Singhbhum granite phase III, (iii) 250 to $2,200 \mathrm{ohm}-\mathrm{m}$ for lower crust (iv) 3,000 to 47,000 ohm for the upper mantle and (v) 200 to $2300 \mathrm{ohm}-\mathrm{m}$ for the asthenosphere. Sharp break in electrical resistivity at the (i) upper crust-lower crust (ii) lower crust upper mantle and (iii) lithosphere-asthenosphere boundary is obtained along the entire profile. Signals could see up to $100 \mathrm{~km}$ below the granite batholith. Singhbhum granite phase II and III could be demarcated on the basis of resistivity. Low resistive zones in the lower crust and upper mantle might have formed due to (i) water (ii) combined effect of water and carbon and (iii) high temperature and partial melt.
\end{abstract}

Keywords. Magnetotelluric survey; Singhbhum granite batholith; inversion model; magnetometer array.

\section{Introduction}

Electrical conductivities of the crust and the upper mantle, like seismic velocity, density and magnetic susceptibility are important constraints on the physical properties for mapping large scale crust-mantle structures which may throw some light on the processes of crustal evolution. With the recognition of a distinct ancient crustal block (iron ore craton) in the Singhbhum-Orissa region of eastern India (Sarkar and Saha 1959), attention of many geologists has been drawn to this region to study the structural, petrological and geochronological aspects of this Archaean terrain. Some of the oldest exposed rocks of the earth viz older metamorphic group (OMG) and older metamorphic tonalite gneiss (OMTG) (3800 million years) are reported from this area (Basu et al 1981). The crust under this iron ore craton is reported to have evolved over 3.0 Ga ago. Saha et al (1988), and Ghosh et al (1986) have given the evolutionary sequence of this region, which is dominated by the Singhbhum granite batholith and other batholiths during Archaean time. Mayurbhanj granite was emplaced along the eastern flank of the Singhbhum granite during Proterozoic time. An active sequence of geological events in this region from $\mathrm{C} \mathrm{3.8}-0.9 \mathrm{Ga}$ has been worked out (Cf. Saha et al 1988). The Singhbhum-Orissa iron ore craton contains 
batholithic bodies of granites and granodiorities as well as Archaean-Proterozoic volcano-sedimentary supracrustals and some mafic intrusives. This cratonic block is bounded by the arcuate copper belt thrust zone in the north and the Sukinda thrust zone in the south. It is surrounded in the east and north by the relatively high grade metamorphic satpura belt and in the south by the granulite facies Eastern Ghat belt.

The major crust-forming events in the Singhbhum craton were complete by $3.0 \mathrm{Ga}$ and the major crustal growth continued up to $950 \mathrm{Ma}$ (Saha et al 1988). The area under investigation is geologically one of the most well studied areas of the world. Therefore, the readers are referred to the original papers (Saha et al 1984, 1988; Saha and Roy 1984a, b, 1988; Ghosh et al 1986) for geological information.

Except for detailed gravity measurements of Verma et al (1984), no significant geophysical work has been reported on this shield area. Therefore, the electrical characterization of this ancient cratonic block of eastern India was chosen as one of the major problems in this project. Accordingly, magnetotelluric sounding and magnetometer array studies were proposed for the area and the programmes were jointly undertaken by the Indian Institute of Technology Kharagpur, the Indian School of Mines Dhanbad and the Indian Institute of Geomagnetism Bombay. Attempts to throw light on the evolutionary history of the Singhbhum granite batholith, based on geochronological work have been made by Basu et al (1981), Saha et al (1986) and Baksi et al (1987).

\section{Field work and one-dimensional inversion model}

Single site magnetotelluric field was surveyed across the Singhbhum granite batholith along the NE-SW profile (figure 1). Location of the observation points is also shown in the figure. The field sites were chosen about 1 to $2 \mathrm{~km}$ inside from National Highway No. 6 to avoid any cultural noise as far as practicable. The distances between the observation points varied from 6.50 to $15 \mathrm{~km}$. The total length of the traverse was about $100 \mathrm{~km}$.

Metronix (MMSO2E) system was used for field measurements. Two pairs of silver-silver chloride electrodes were placed at a distance of about $100 \mathrm{~m}$ each in two mutually perpendicular directions (east-west and north-south) to measure the electric field compounds $E_{x}$ and $E_{y}$. Magnetic fields $\left(H_{x}\right.$ and $\left.H_{y}\right)$ are measured along the east-west and north-south directions putting the induction coils in horizontally dug grooves. Induction coils were aligned and levelled with a prismatic compass and spirit level.

The period of measurement ranged from 0.25 to 4096 seconds in this equipment. Measurements were done in three bands LF1 (256 to 4096s), LF2 (8 to 256s and LF3 $(0-25$ to $8 \mathrm{~s})$. Figures 2 to 4 show the samples of time series in LF3, LF2 and LF $I$ bands. Observations at one field station were taken for about 12 hours; overnight observation was preferred to day-time observation in summer. Monovariate coherency threshold for $E_{x}-H_{y}$ and $E_{y}-H_{x}$ was kept at 0.85. Coherency threshold should be kept within 0.8 to 0.9 (Kurtz and Garland 1976; Kaufman and Keller 1981; Rankin and Pascal 1985a, b). Lesser the value of $H_{x}-H_{y}$ coherency, more stable will be the computed impedances. The value of this coherency should preferably be 0.6 (Swift 1969; Rankin and Pascal 1985a, b). Typical field values of apparent resistivity, phase and the monovariate and bivariate coherencies for the stations Dudura and Dari are presented in tables 1 and 2 . Figures 5 to 8 show the apparent resistivity and phase 
Magnetotelluric survey across Singhbhum

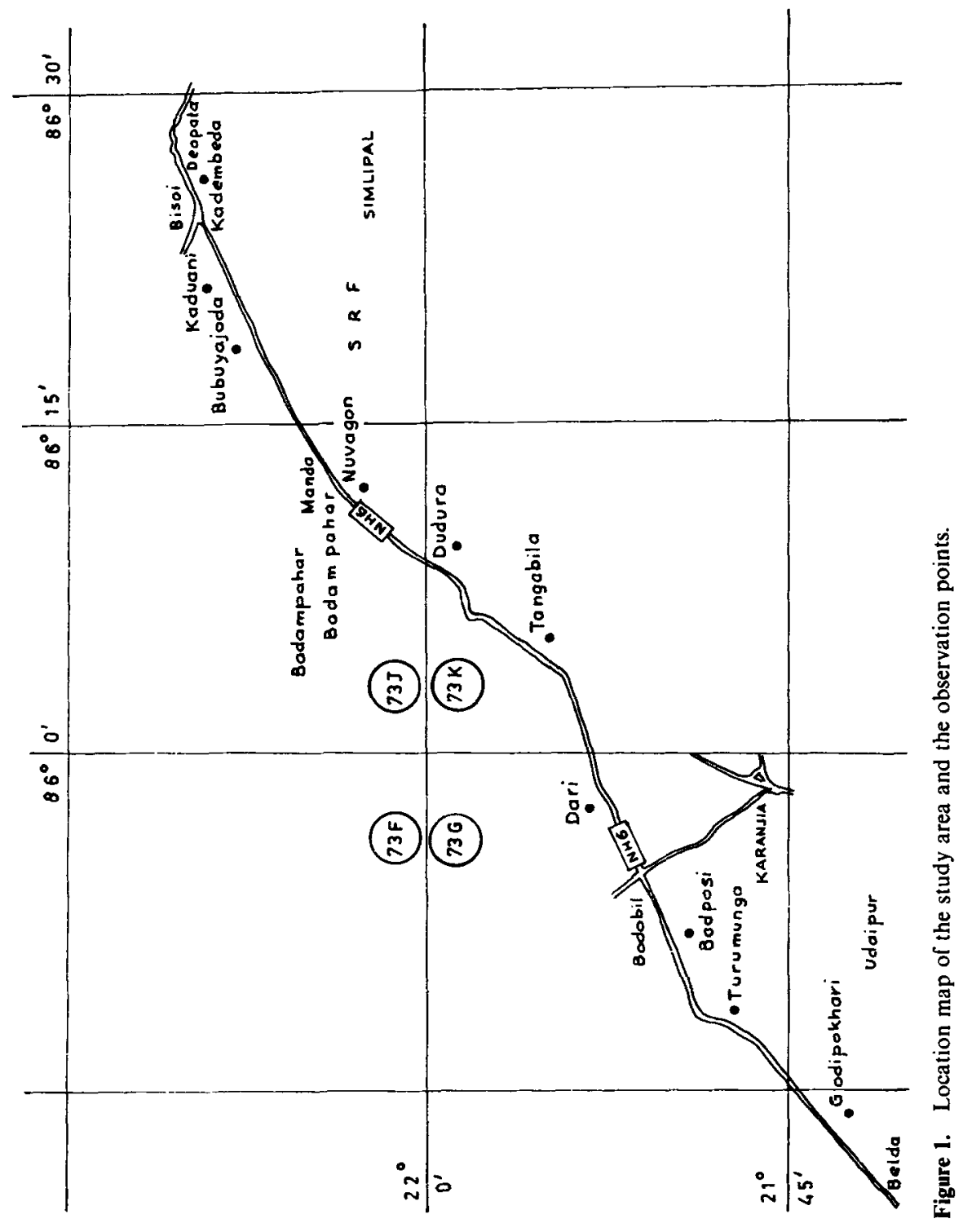




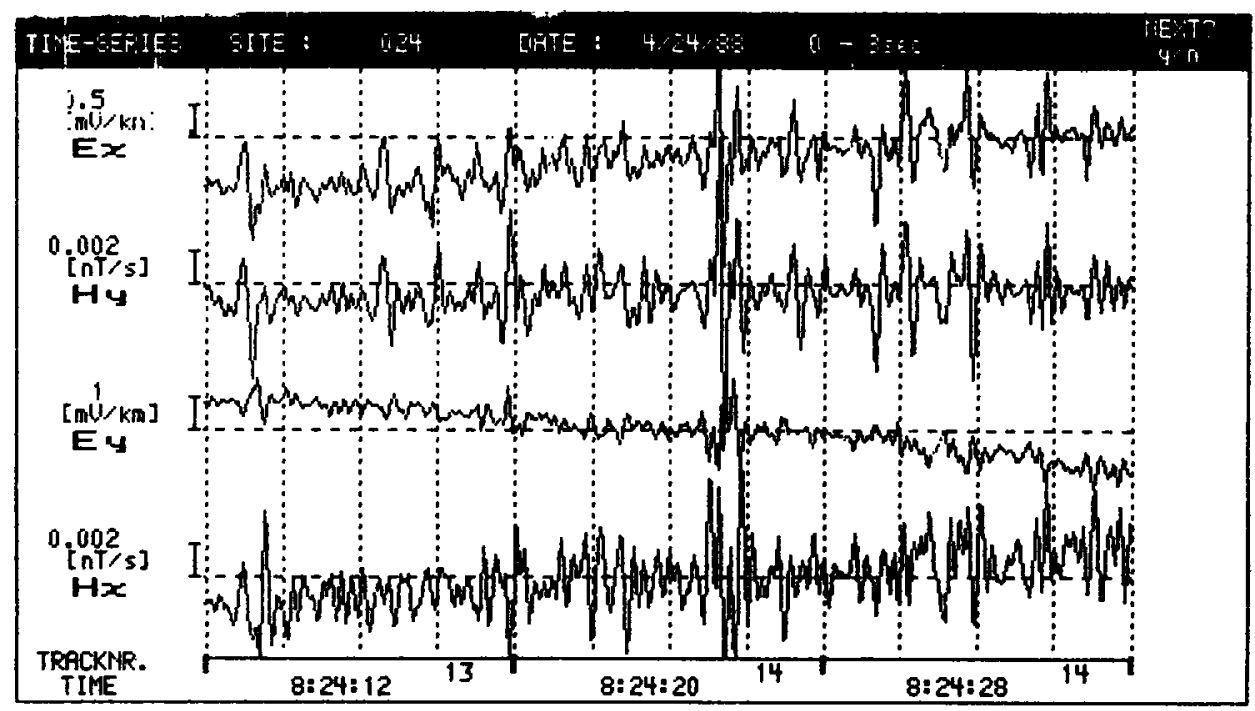

Figure 2. Time series, LF3 band, location village Dari, dated 24.4.88.

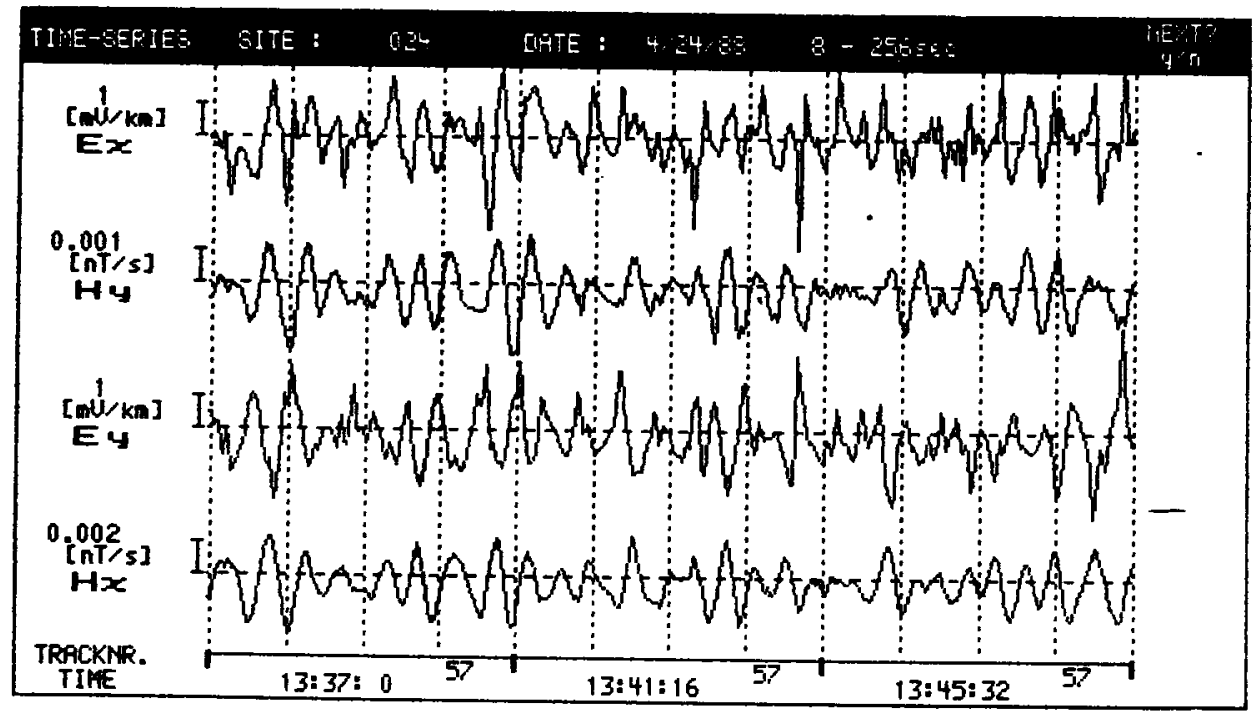

Figure 3. Time series LF2 band, location village Dari, dated 24.4.88.

curves for the station Dudura and Dari for $Z_{x y}$ and $Z_{y x}$. Figures 9 to 12 show the one-dimensional (1D) MT inversion results for $Z_{x y}$ and $Z_{y x}$ with optimum rotation. Observations of only two stations are presented in this paper on account of space limitations. Optimum rotation of the impedance tensor is given to minimize $Z_{x x}^{2}+Z_{y y}^{2}$ and maximize $Z_{x y}^{2}+Z_{y x}^{2}$ (Vozoff 1972). Since Singhbhum granite is a huge batholitic body, the $1 \mathrm{D}$ model and inversion with optimum rotation angle is justified on the central part of the body (Jones and Hutton 1979). Figure 13 shows the geoelectric section drawn on the basis of the mean depths, thicknesses and resistivities obtained from rotated $Z_{x y}$ and $Z_{y x}$. 


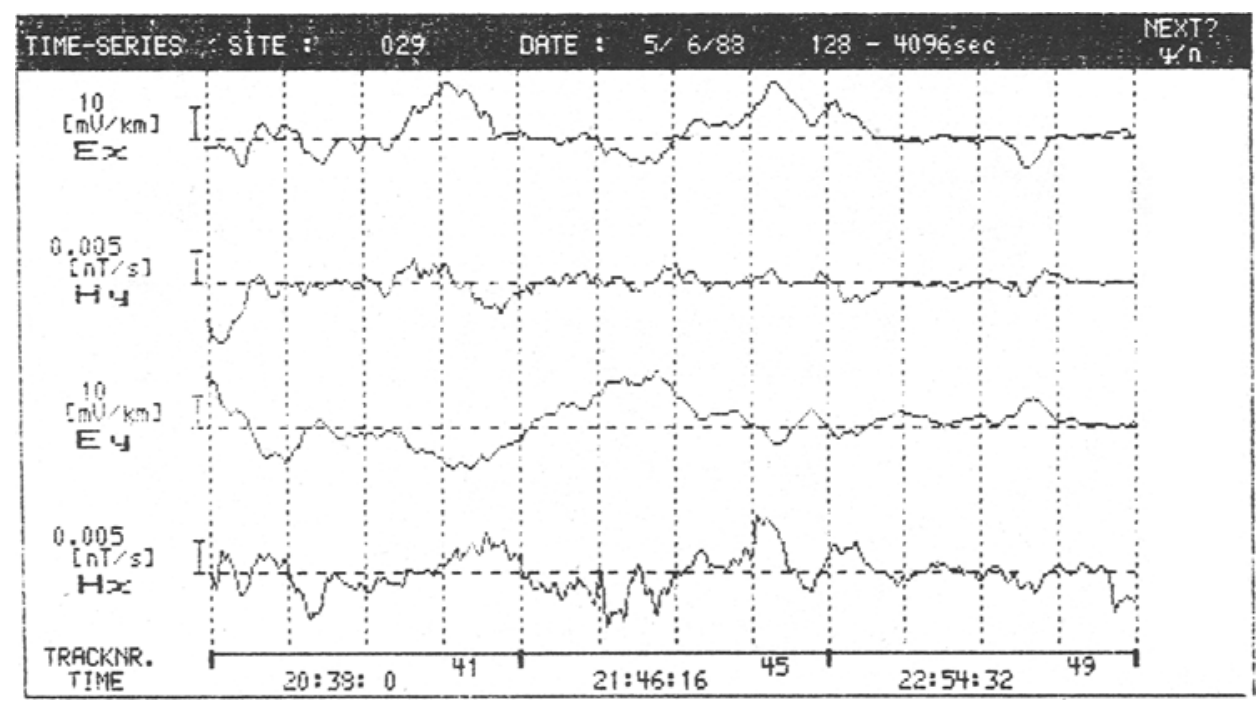

Figure 4. Time series LF1 band, location village Baliaguda, dated 6.5.88.

MT observations were taken with a single measurement without any remote reference facility. Out of 30 stacks in the frequency bands, 12 to $20 \mathrm{~s}$ at the different frequencies could be retrieved at different observation points. Long-period observations greater than 600 seconds did not cross the coherency threshold. The present investigation depth was therefore restricted to a maximum of 100 to $150 \mathrm{~km}$. Signals with a period range of 1.33 seconds to 5.33 seconds were weaker and in most of the soundings, no signals were stacked. This zone is generally called the dead zone.

\section{Interpretation}

Electrical resistivities of granites and granodiorities varied from $2,500 \mathrm{ohm}-\mathrm{m}$ to nearly $100,000 \mathrm{ohm}-\mathrm{m}$. Although the in situ resistivity of the order of $10^{5} \mathrm{ohm}-\mathrm{m}$ for crust mantle silicates is a little on the higher side, several workers (Kurtz and Garland 1976; Vanzijl 1978; Kurtz 1982; Beamish 1986) have reported such higher orders of resistivity. Resistivity of the Singhbhum granite phase II (3.3 billion years) is considerably higher than that of Singhbhum granite phase III ( $3 \cdot 1$ billion years). MT section could demarcate the boundaries of phases II and III granite. Phase II granite is older, more acidic, with low density and low level of radioactivity. Phase III granites are assumed to be the recrystallization products of phase II granite. Therefore, phase III part is richer in uranium and thorium content and mafic minerals. MT signals with a $4 \mathrm{HZ}$ frequency did not see the top $10 \mathrm{~km}$ of the granite batholith.

Low resistive zone at the base of the lower crust was present in the entire survey area. Crustal conductors in the continental shield areas were reported by several workers (Keller et al 1966, Mitchell and Landisman 1971, Adam 1978, Vanzijl 1978, Jones $1982 \mathrm{a}, \mathrm{b}$ ). The presence of crustal conductors in the shield areas has become more a rule than an exception. The reason for the conductive lower crust may be due to: (i) graphite mineralization (ii) water in the lower crust (iii) fractures, fissures 


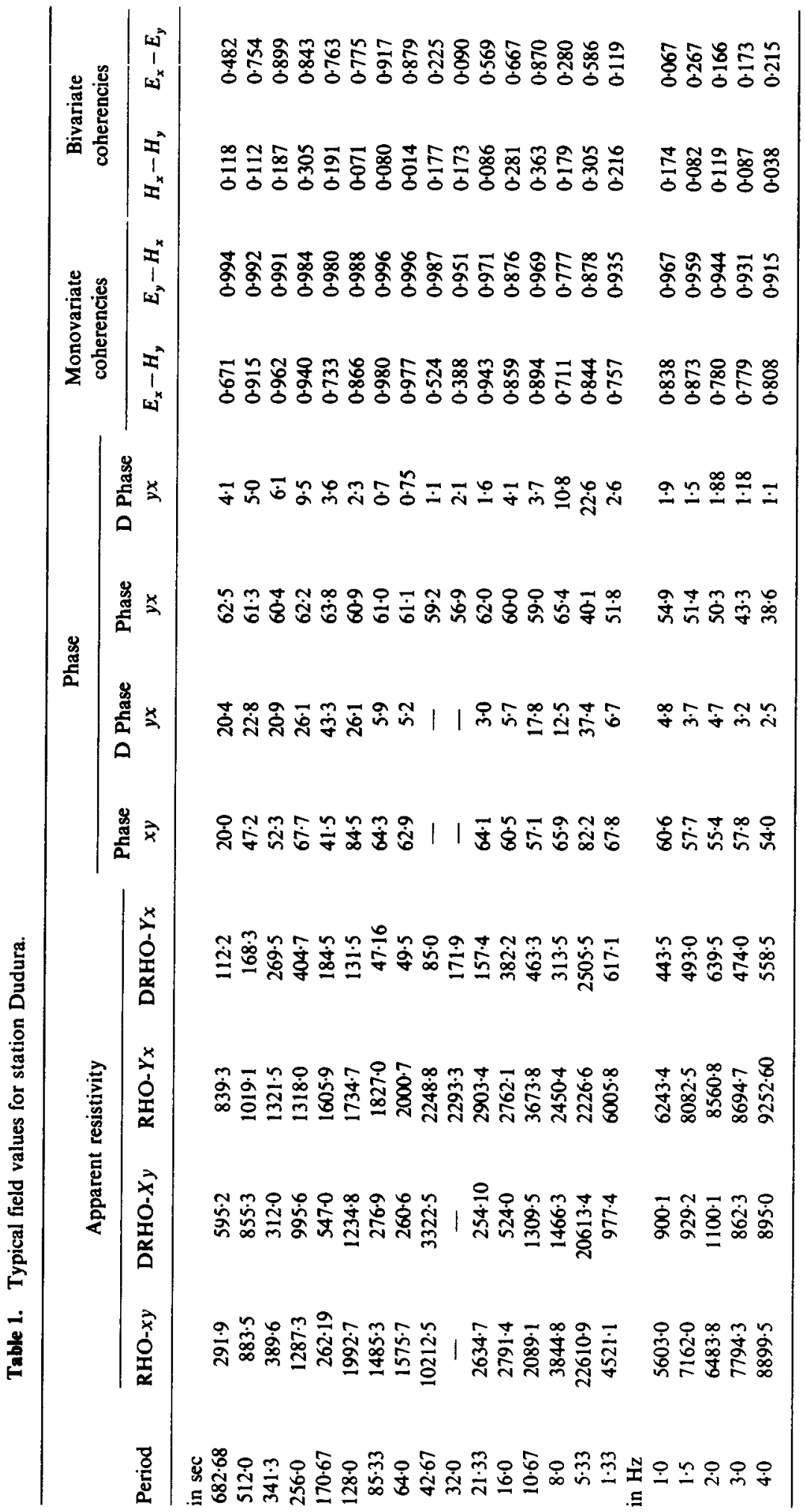




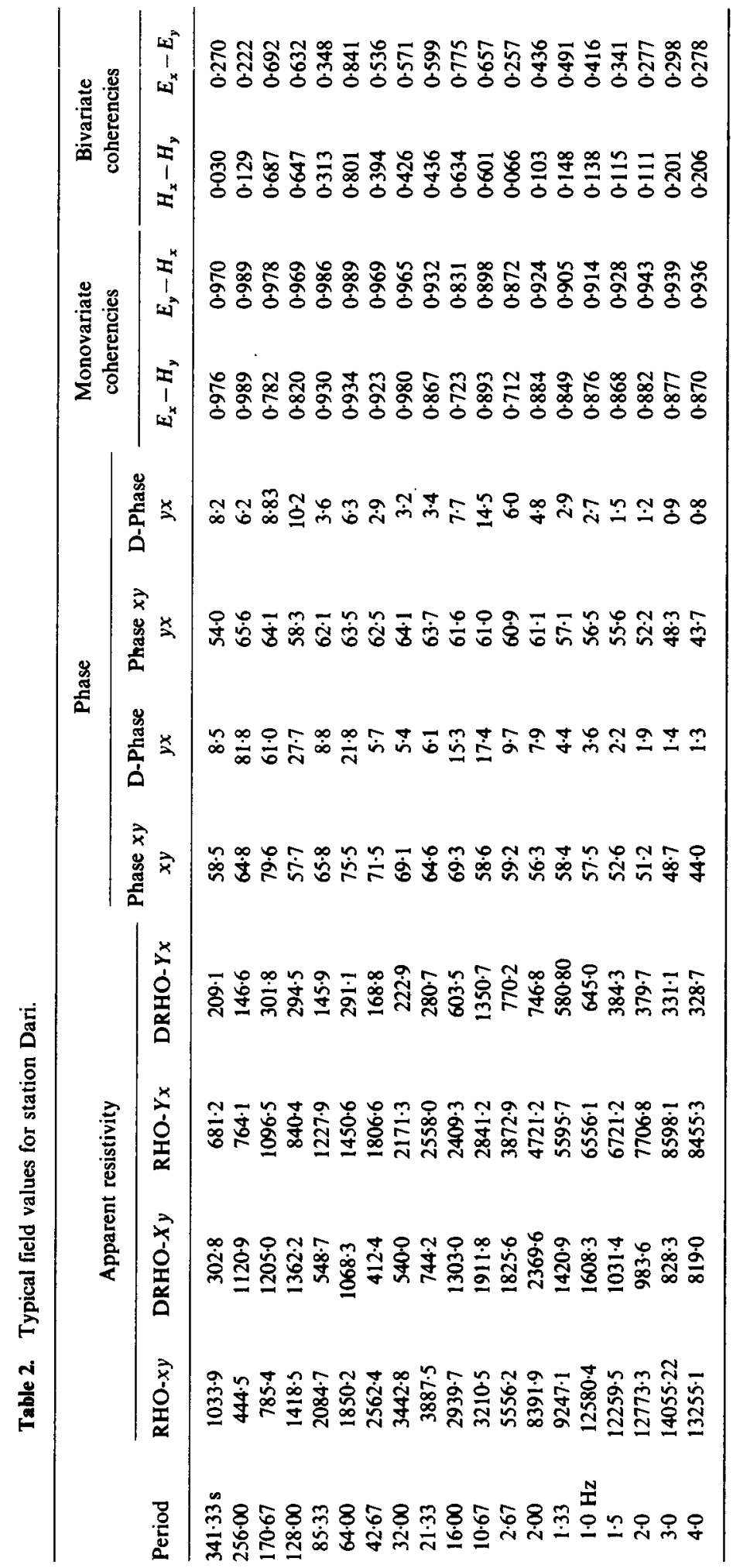



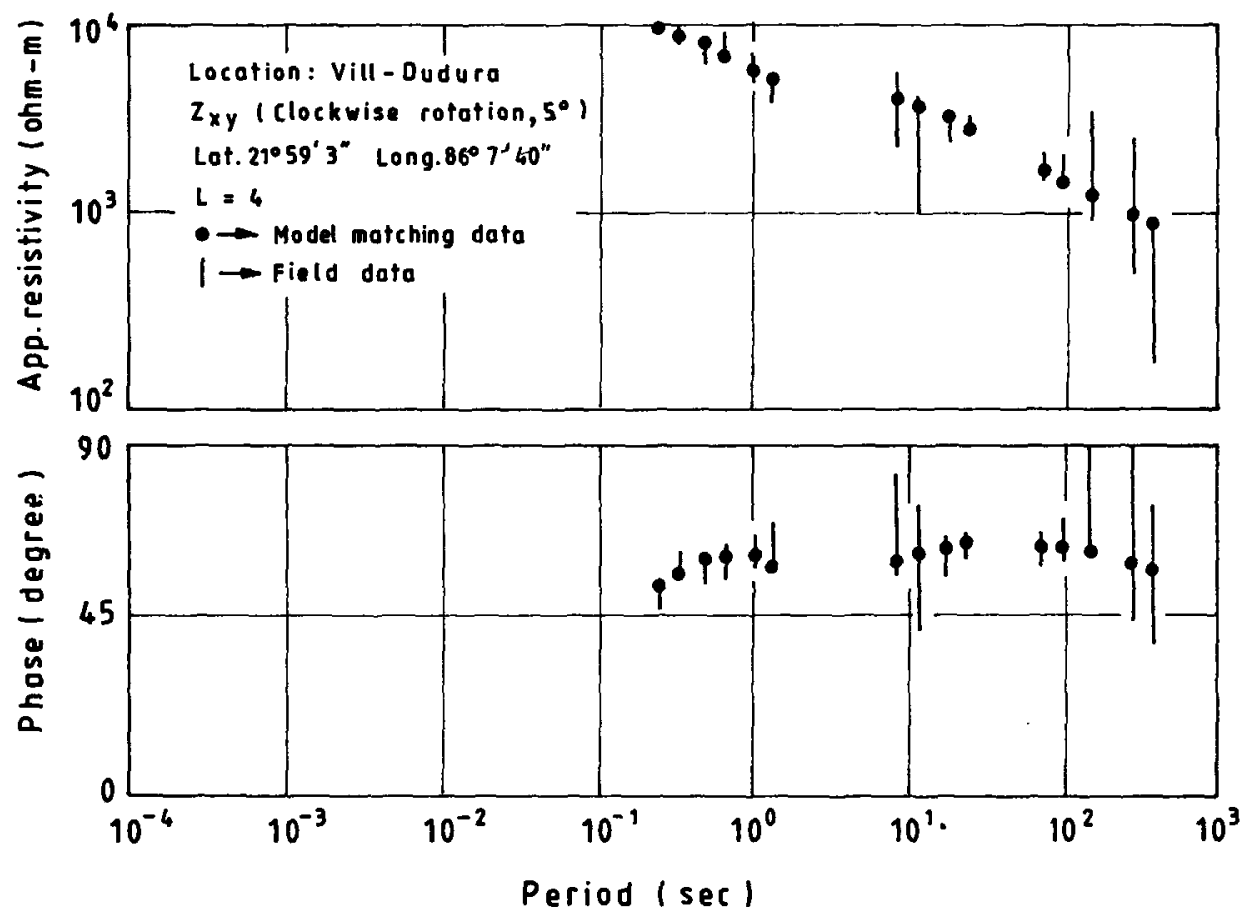

Figure 5. MT apparent resistivity $\left(\rho_{x y}\right)$ and phase $\left(\phi_{x y}\right)$ vs time-period; location Dudura.
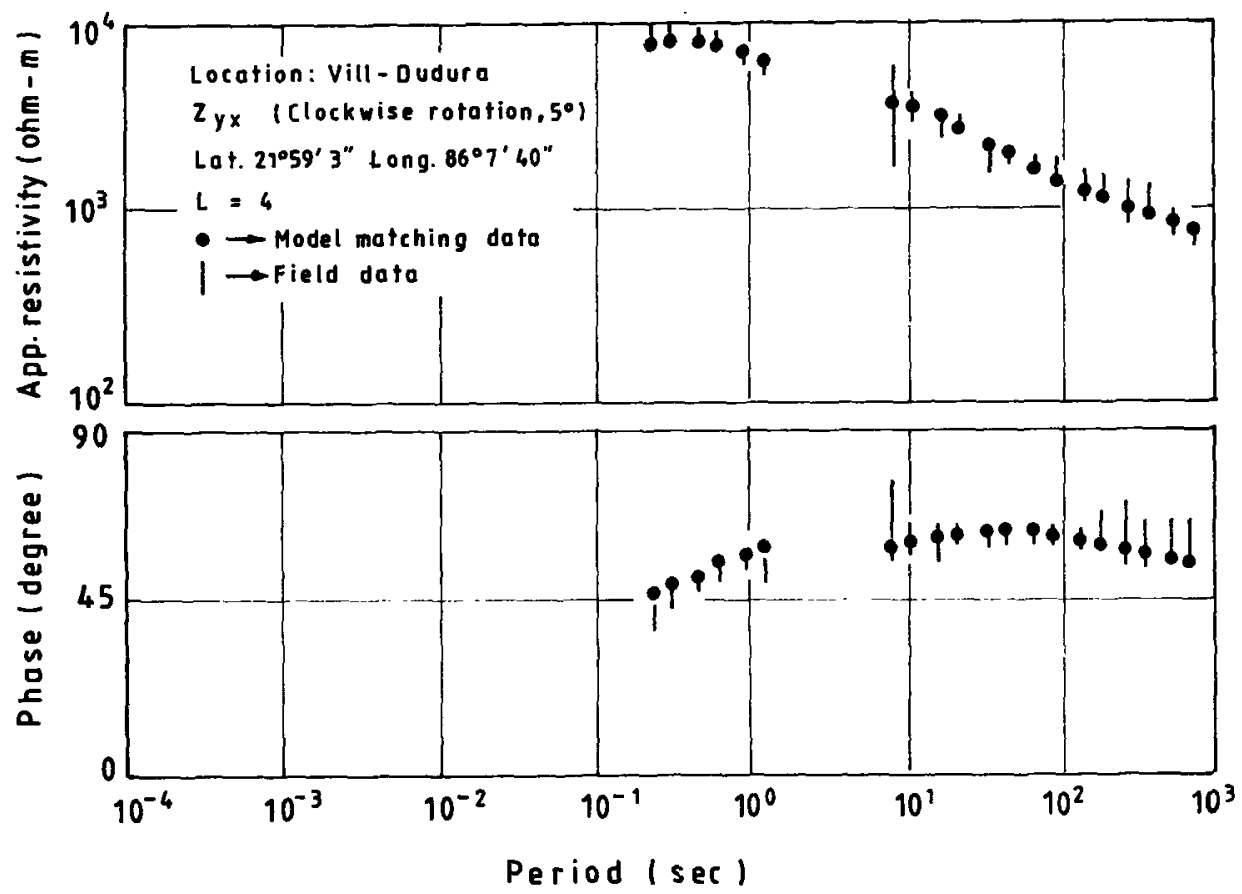

Figure 6. MT apparent resistivity $\left(\rho_{y x}\right)$ and phase $\left(\phi_{y x}\right)$ vs time period; location Dudura. 

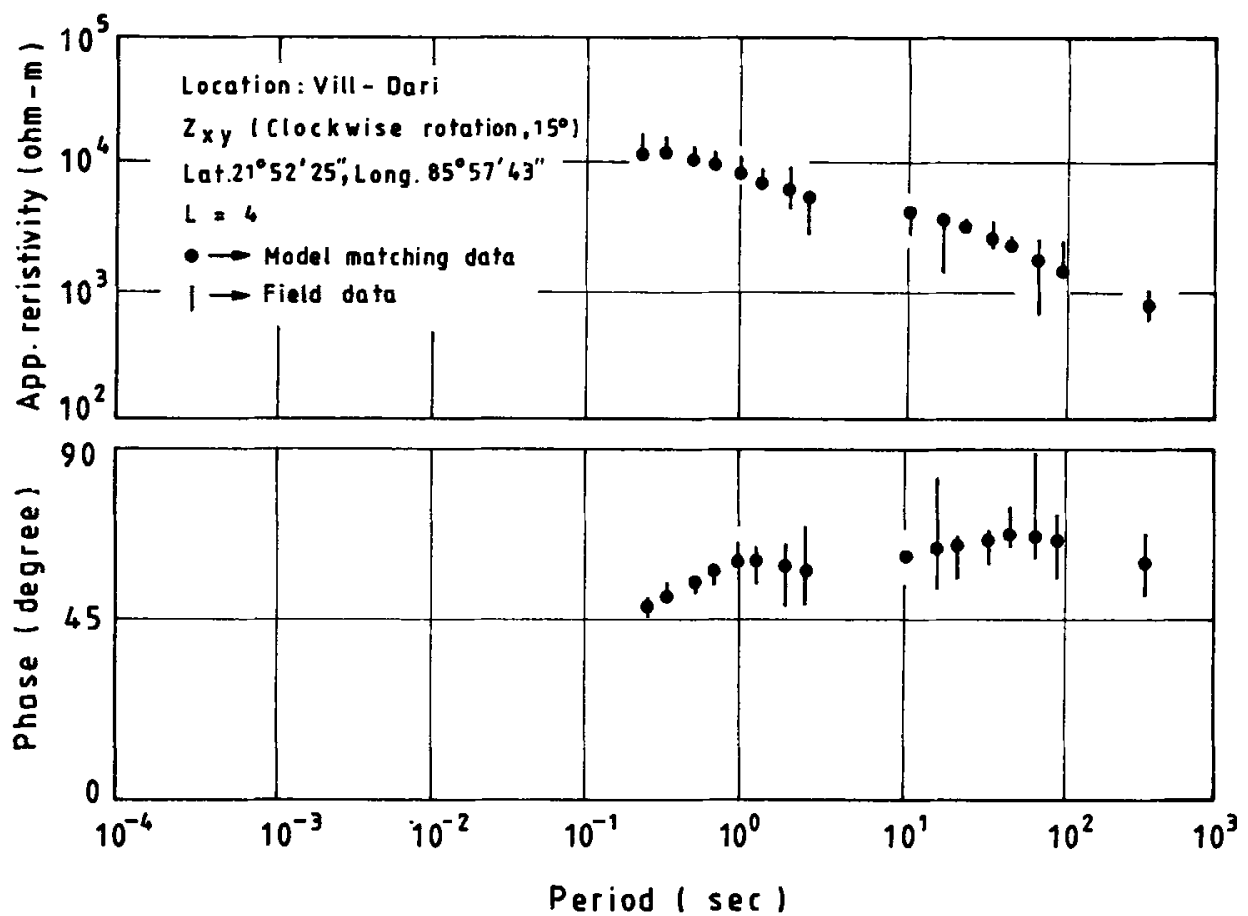

Figure 7. MT apparent resistivity $\left(\rho_{x y}\right)$ and phase $\left(\phi_{x y}\right)$ vs time period; location Dari.
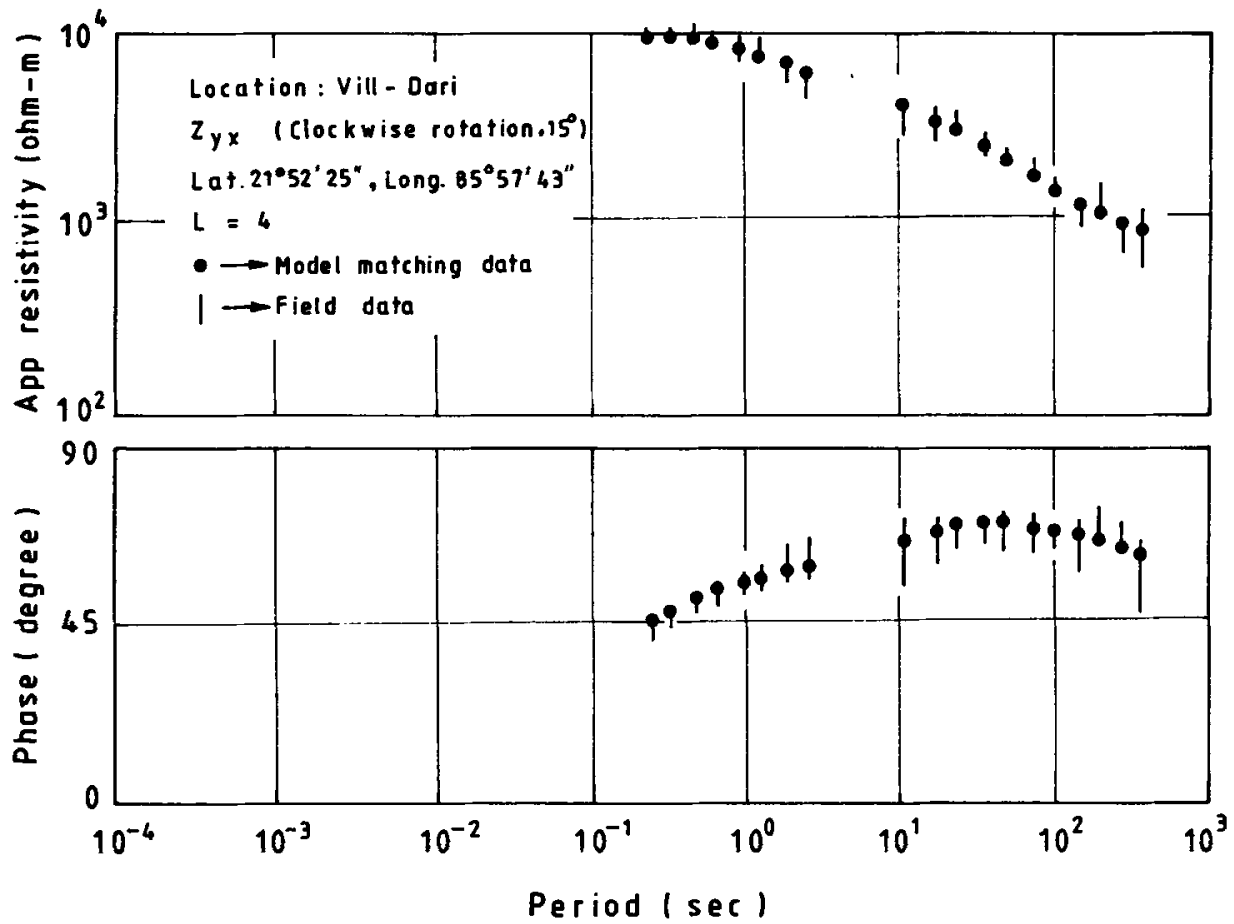

Figure 8. MT apparent resistivity $\left(\rho_{y x}\right)$ and phase $\left(\phi_{y x}\right)$ vs time period; Location Dari. 


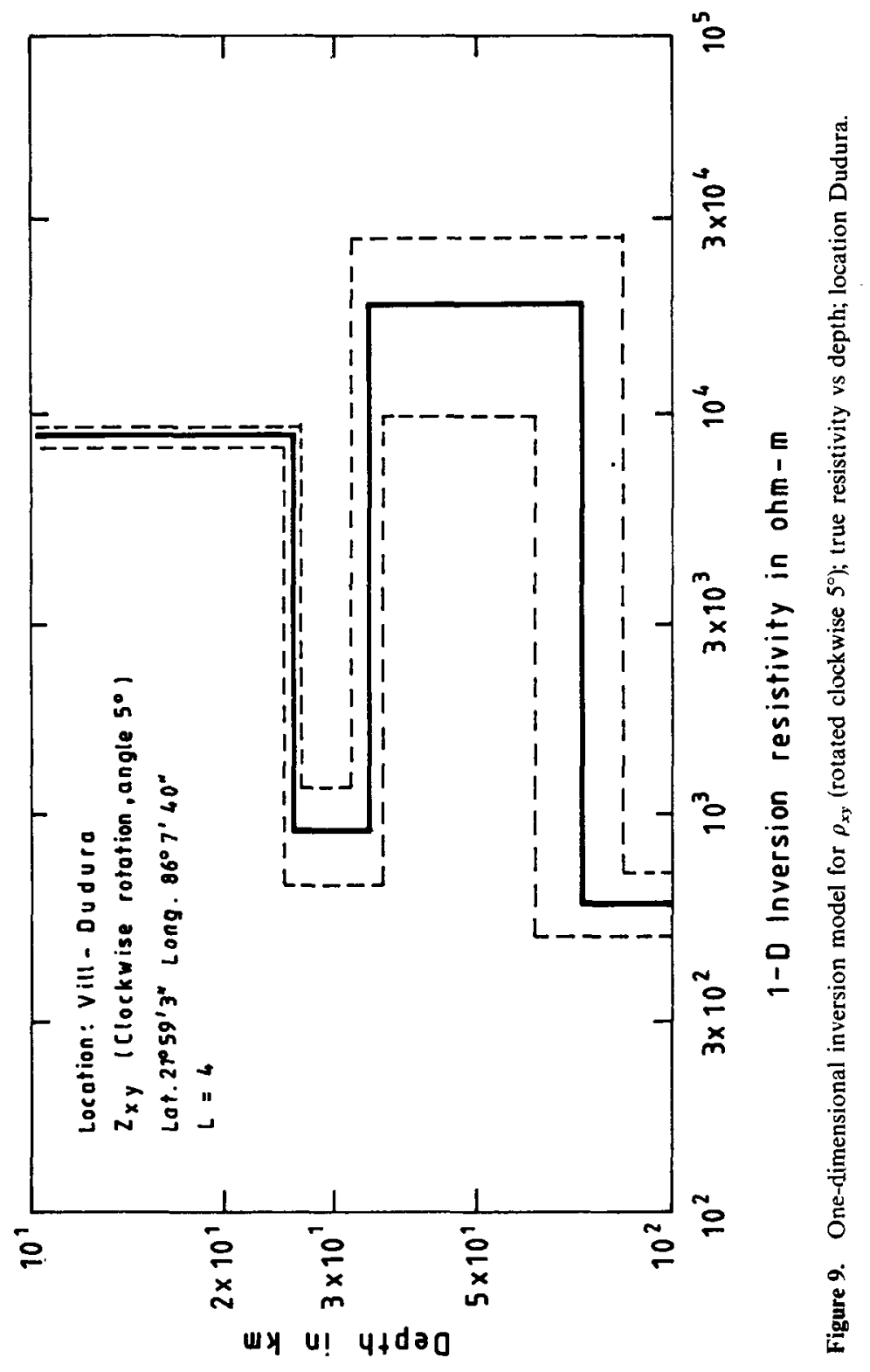




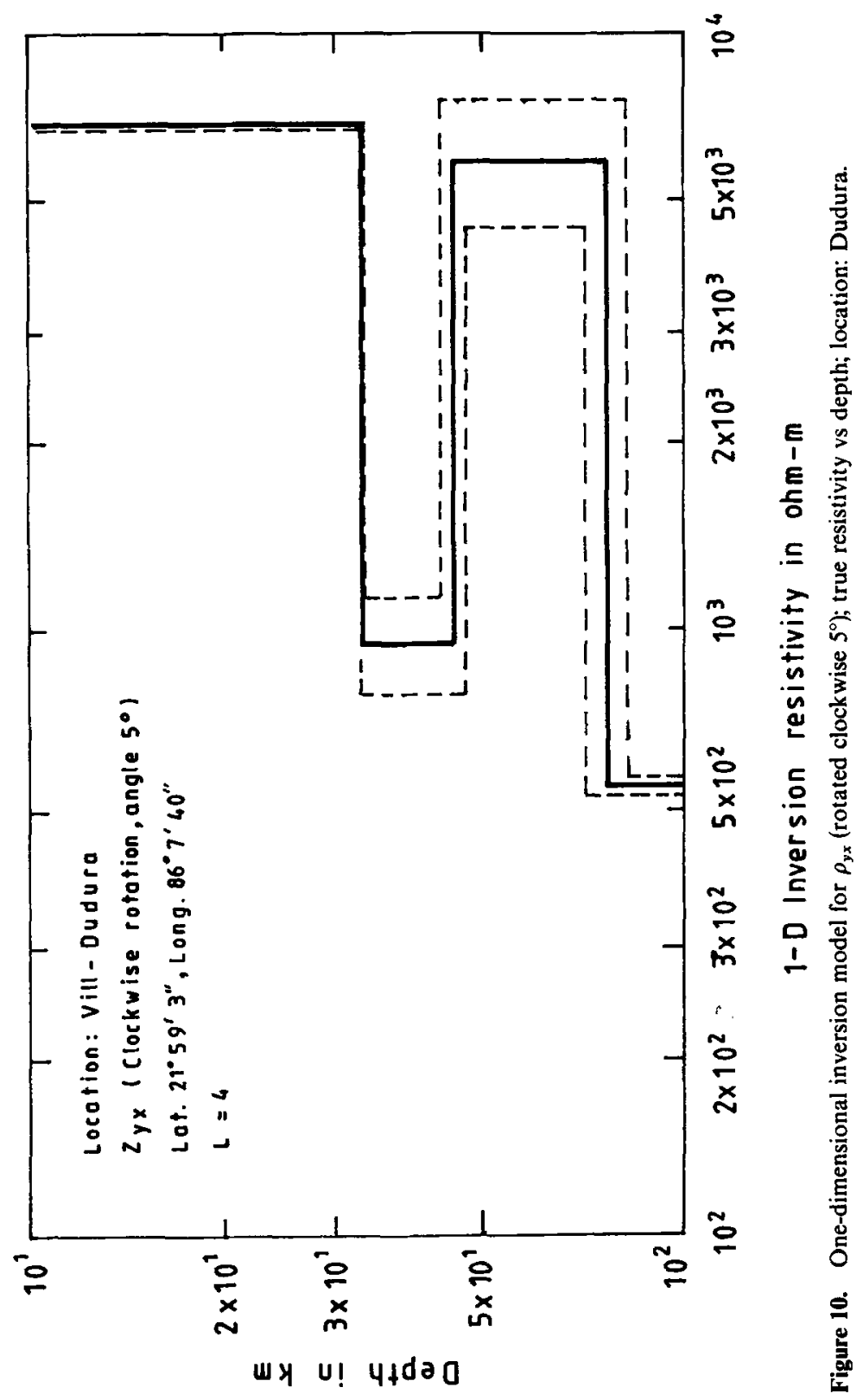




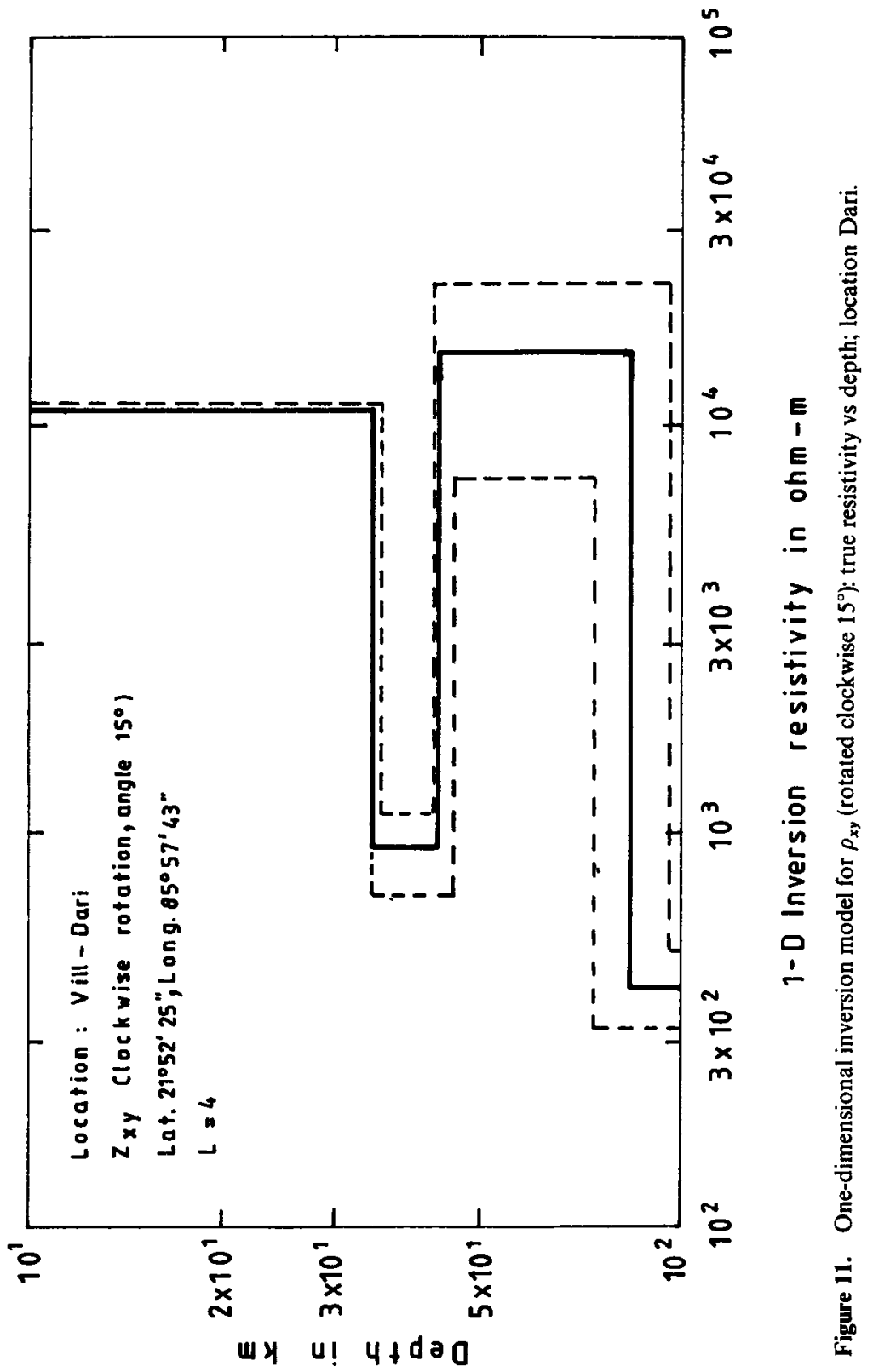




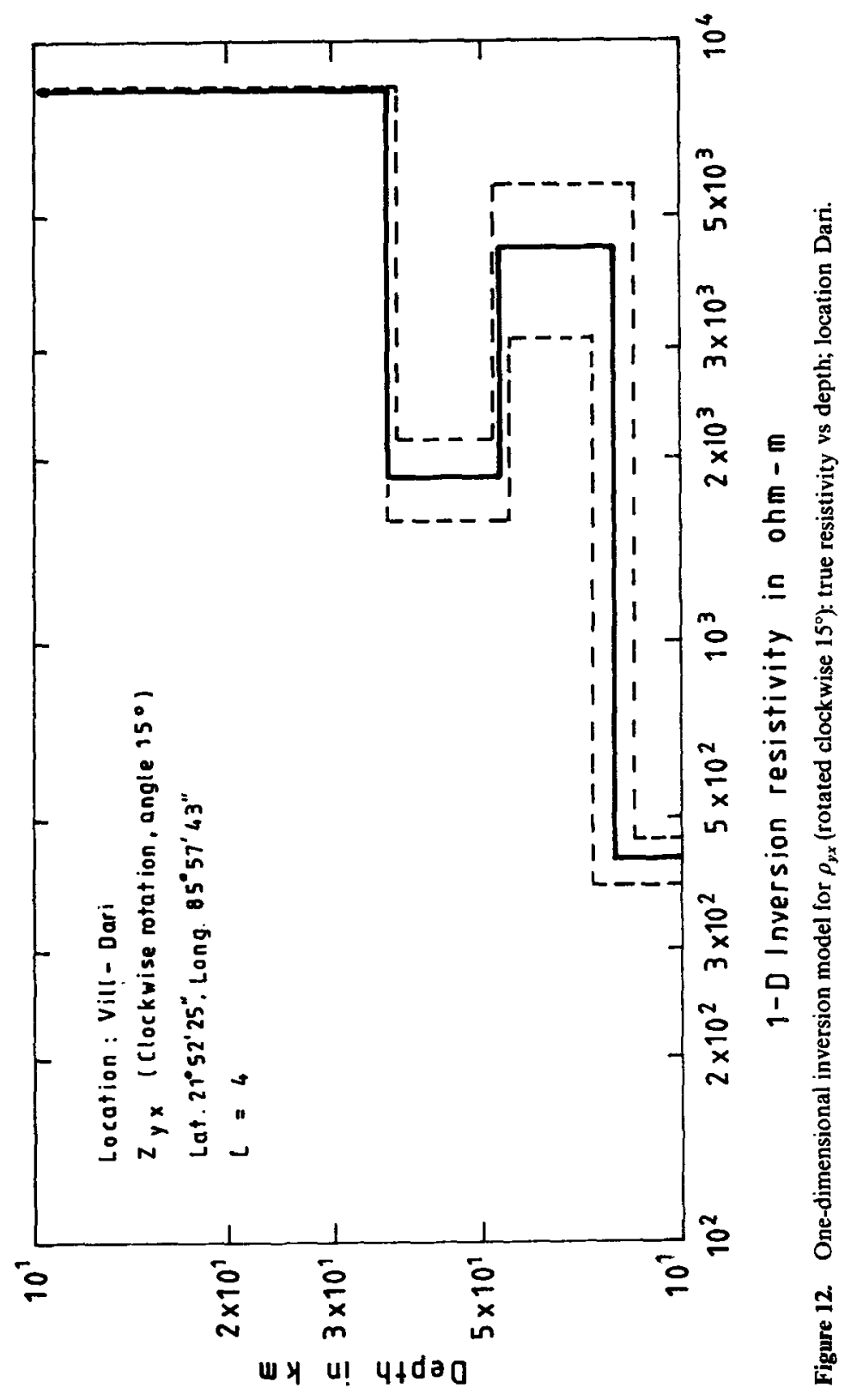




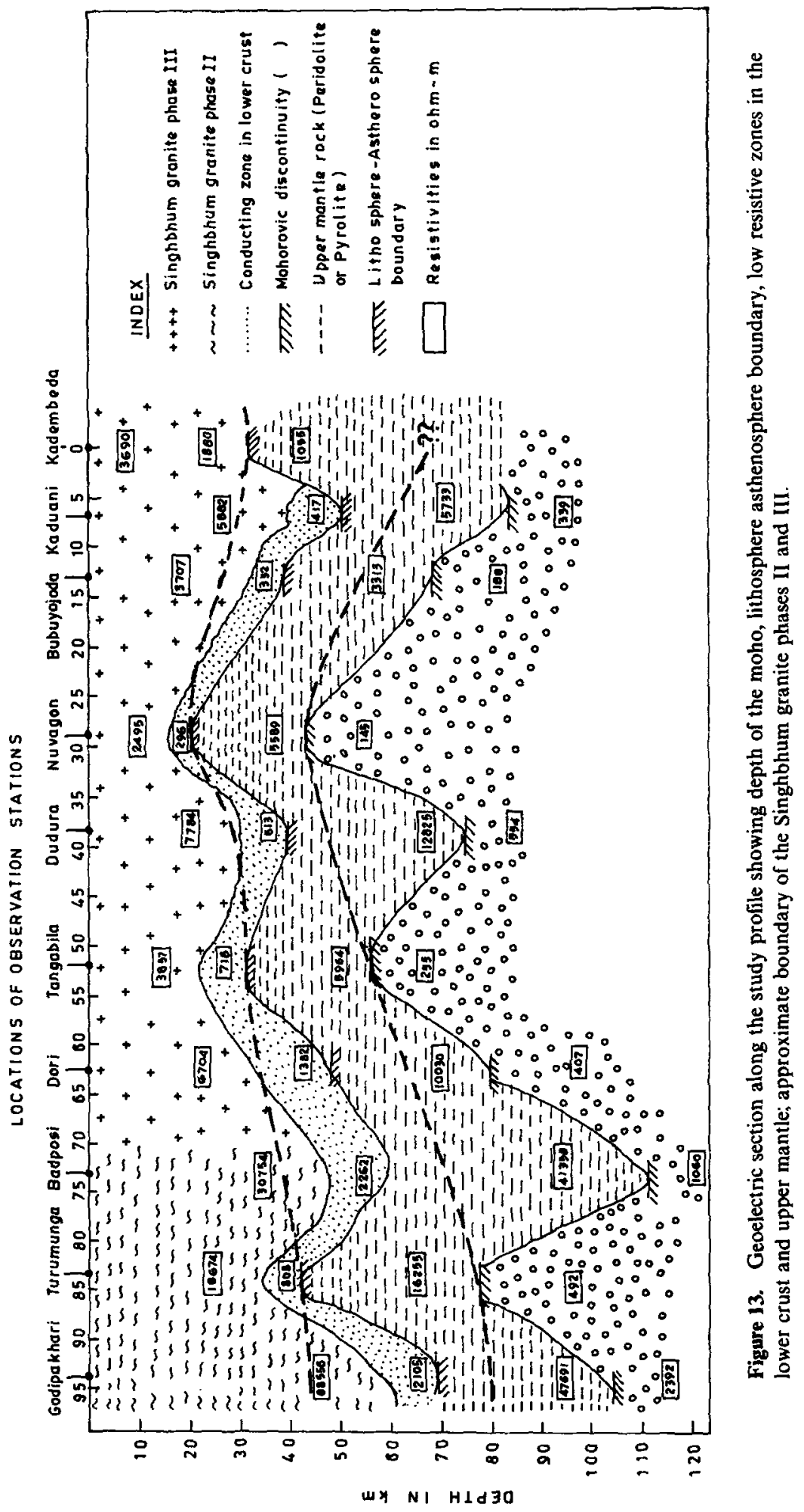


and intergranular porosity of 0.1 to $0.01 \%$ (iv) partial melt pockets (v) hydrated minerals including clays and (vi) radiogenic heat. Adequate weightage can be given to three distinct possibilities in the absence of heat flow and deep seismic sounding data.

(i) Partial melt at the lower crustal depth at $8-9 \mathrm{~kb}$ pressure and about 500 to $600^{\circ} \mathrm{C}$ temperature is not expected unless the anomalous high heat flow supports the existence of partial melt. Practically no heat flow data of this region are available. Rao et al (1976) reported relatively high heat flow in the Singhbhum shear zone. Singh and Negi (1982) opined that the upper mantle temperature increases beneath the Indian shield as one goes towards the north from the peninsular gneisses in south India. They suggested the moho boundary to be $850^{\circ} \mathrm{C}$ to $950^{\circ} \mathrm{C}$ beneath the Singhbhum granite. This proposition is against the generally accepted idea that the mantle below the shield areas is cooler than those of the continental and oceanic upper mantle. However, opinions in favour of higher heat flow through the continental shield areas have been expressed by some (Verma et al 1966; Beck and Sass 1966; Sass et al 1968; Carte and Van Rooyen 1969; Jaeger 1970) and those in favour of colder upper mantle beneath the shield area have been expressed by others (Lee and Uyeda 1965; Polyak and Smirnov 1968; Haroi and Simmons 1969; Lachenbruch 1970; Lacheubruch and Bunker 1971).

The geothermal gradient below the granitic crust varies from $15^{\circ}$ to $30^{\circ} \mathrm{C}$ per kilometer near the surface and decreases gradually with depth leading to the temperature of about 500 to $600^{\circ} \mathrm{C}$ near the moho boundary. Most of the cases granites grow in the crust itself by fractional crystallization of the basaltic magma which in turn originates from the pyrolyte partial melts in the upper mantle. One can, therefore, set $20 \mathrm{~km}$ arbitrarily as the unknown depth of the floor of the Singhbhum granite batholith (Turner and Verhoogen 1951) leaving room for the amphibolite/granulite facies rocks to occupy the lower crustal depth. Although gabbro and amphibolite melt at $650^{\circ} \mathrm{C}$ and $700^{\circ} \mathrm{C}$ respectively at 8 to $9 \mathrm{~kb}$ pressure, Wyllie (1977) showed experimentally that a little fraction of water can significantly reduce the melting point of the crust-mantle silicates. Shankland and Waff (1977) demonstrated experimentally that a small increase in melt fraction in a partially molten silicates can significantly increase its electrical conductivity. Therefore, the presence of partial melt in the conducting layers is a distinct possibility.

(ii) Reasonably good reports of the presence of water in the upper, lower crust and upper mantle are available in the papers by Hyndeman and Hyndeman (1968), Mitchell and Landisman (1971), Fyfe et al (1978), Shankland and Anders (1983) and Haak and Hutton (1986). Water can come to the upper and lower crust through fractures and fissures. However, the presence of water in the lower crust and upper mantle does not demand its percolation from the surface. Water can originate within the crust from (i) muscovite in the presence of quartz (ii) epidote minerals in the presence of quartz (iii) chlorite in the presence of $\mathrm{K}^{+}$and $\mathrm{Al}^{+++}$ions (Mitchell and Landisman (1971) and (iv) $\mathrm{CO}_{2}$ in the presence of methane $\left(\mathrm{CO}_{2}+\mathrm{CH}_{4} \rightarrow 2 \mathrm{C}+2 \mathrm{H}_{2} \mathrm{O}\right.$ (Ballhaus and Stumpft (1985). Water can come from serpentines (Stesky and Brace (1973) and other hydrated minerals (Drury and Hyndeman 1979). Retrogressive metamorphism due to downward percolation of water in anhydrous acidic granulite leading to the formation of serpentines can also account for the increased conductivity. Therefore, the presence of water for one or more reasons in the crust and mantle as a continuous phase can explain the decrease in resistivity of the lower crust.

(iii) Alabi et al (1975), Garland (1975) and Sternberg and Clay (1977) have mentioned 
that the electrical conductivity in the lower crust and upper mantle may be due to graphite mineralization. Diamond originates at a depth of $150 \mathrm{~km}$ at roughly $1400^{\circ} \mathrm{C}$ and 30 to $40 \mathrm{~kb}$ pressure at the base of the lithosphere. Its phase transition from diamond to graphite occurs at a rapid rate above $1000^{\circ} \mathrm{C}$ (Clifford and Kennedy 1982). The origin of carbon and water from carbon dioxide and methane in the upper mantle (Ballhaus and Stumpft (1985) and upliftment of the carbon either by carbon dioxide or by Kimberlite pipes give clues to argue that upper mantle and lower crust contain carbon in ppm. Duba and Shankland (1982) mentioned that even a few ppm of carbon either in amorphous or crystalline form can form an interconnected phase and can significantly increase the electrical conductivity. Since graphite is a highly conducting mineral, breaking of carbon dioxide to carbon and water in the presence of methane (Woermann et al 1985) can explain the enhanced electrical conductivity. Here, the contribution comes from both carbon and water. Some weightage can be given to the presence of sulphur (Stanley et al 1977; Olhoeft 1981; Jiracek et al 1983) and magnetic oxides (Stesky and Brace 1973; Shankland and Anders 1983; Haak and Hutton 1986) which can explain the enhanced electrical conductivity in the crust.

Figure 13 shows the depth of the moho and lithosphere asthenosphere boundary obtained on the basis of breaks in electrical conductivity using Schmucher algorithm for 1D inversion. Although Vanzijl (1978), Kurtz and Garland (1976) and Jones $(1982 a, b)$ have shown that electrical conductivity can detect the moho and lithosphere asthenosphere boundary, discontinuities in seismic velocity and electrical conductivities may not coincide in all cases. Therefore, we call the moho and LA boundary as electrical moho and electrical lithosphere asthenosphere boundary.

Thicknesses of the crust and lithosphere on the basis of $1 \mathrm{D}$ inversion of MT data and avoiding high skewness $\left[S=\left(Z_{x y}+Z_{y y}\right) /\left(Z_{x y}-Z_{y x}\right)\right]$ stations are found to vary between 23 and $45 \mathrm{~km}$ and 45 and $80 \mathrm{~km}$ respectively. $1 D$ inversion for low skewness stations for optimum rotation of the MT tensors $Z_{x y}$ and $Z_{y x}$ is taken with certain confidence. Averages of the interpreted depths obtained from $Z_{x y}$ and $Z_{y x}$ are used in figure 11. Some of the reported lithospheric thicknesses are (i) Cantwell et al (1965)-60 km (ii) Turner and Verhoogen (1951)-60 km (iii) Windley (1977)100-150 km (iv) Pollack and Chapman (1977)-45-300 km (v) Gass et al (1973) $50-100 \mathrm{~km}$ (vi) Adam (1980)-70-80 km (vii) Adam et al (1982b)-50-80 km (viii) Cox and Hart (1986) - 80 km (ix) Negi et al (1987)-38-186 km (x) Datt and Batten (1988) -60-250 km. Pollack and Chapman (1977) prepared the global heat flow and lithospheric map on the basis of 12th degree harmonic plot of heat flow data. They have shown the heat flow near Singhbhum craton is $60 \mathrm{mWm}^{-2}$ and lithospheric thickness of about $75 \mathrm{~km}$. One heat flow data from copper belt thrust zone of Singhbhum area are available which is $54.5 \pm 5 \mathrm{mWm}^{-2}$ (Ravi Shankar 1988). Following Chapman and Pollack's (1977) diagram on continental heat flow versus lithospheric thickness, the thickness of the lithosphere is also estimated to be about $100 \mathrm{~km}$.

The wavy nature of the moho and lithosphere asthenosphere boundary obtained by $1 \mathrm{D}$ inversion is assessed at the moment to be due to the $3 \mathrm{D}$ effect in $1 \mathrm{D}$ inversion. All stations with high skewness have given higher values of layer thicknesses.

Lithospheric thickness as low as $45 \mathrm{~km}$ needs verification from DSS and heat flow studies. Such low lithospheric thickness suggests hotter upper mantle and crust; (Rao et al 1976; Singh and Negi 1982).

The present investigation was carried out with a single site MT system without 
remote reference facilities. DC dipole sounding or audiofrequency magnetotellurics are necessary to pick up information up to 10 to $15 \mathrm{~km}$ from the surface because MT signals up to $4 \mathrm{HZ}$ frequency did not see the top 10 to $15 \mathrm{~km}$ of the granitic crust.

\section{Acknowledgements}

The first author (KKR) is grateful to the Indian National Committee of IUGG for suggesting the research programme on lithospheric studies and to the Department of Science and Technology, New Delhi for sponsoring this interinstitutional project. He expresses his gratitude to Prof A K Saha of Presidency College, Calcutta who went out of his way to help us in all possible ways in this venture. The authors are grateful to Prof S K Sen of Indian Institute of Technology, Kharagpur for making available his valuable reprint collections and for his valuable suggestions. The authors are grateful to Dr S L Roy of Presidency College, Calcutta who accompanied KKR to the field site to show the geologic settings and the proposed traverses.

KKR is grateful to Prof $R$ K Verma of the Indian School of Mines, Dhanbad for valuable discussions and suggestions. The authors are grateful to Dr Nandini Nagarajan for accompanying us to the field and helping us during the field work. We express our deep sense of gratitude to Mr J Basu, Senior Engineer, Central Instruments Service Section of Indian Institute of Technology, Kharagpur for repairing the field equipment twice during the field season. The authors are grateful to Sri A K Singh for documentation assistance.

We are indebted to Indian Institute of Technology, Kharagpur and DST, New Delhi for sorting out administrative problems during the execution of the project.

\section{References}

Adam A 1978 Geothermal effects in the formation of electrically conducting zones and temperature distribution within the earth; Phy. Earth. Plant. Interiors 17 21-28

Adam A 1980 Relation of mantle conductivity to physical conditions in the asthenosphere; Geophys. Survey 4 43-55

Adam A, Vanyan L L, Varlamov D A, Yegorov I V, Shilovsky A P and Shilovsky P P 1982b Depth of asthenospheric and crustal conducting layers in pannonian basis; Phys. Earth Planet. Inte. 28 251-260

Alabi A O, Cannfield P A and Gough I J 1975 The North American Central Plains conductivity anomaly; Geophys. Jour. Roy. Astr. Soc. 43 815-833

Baksi A K, Archibald D A, Sarkar S N and Saha A K $198740_{\mathrm{Ar}}-39_{\mathrm{Ar}}$ incremental heating study of mineral separates from the early Archaean East Indian Craton: Implication for the thermal history of a section of the Singhbhum granite batholithic complex; Indian Tectonophysics 105 163-176

Ballhaus C G and Stumpft E F, 1985 Occurrence and petrological significance of graphite in the upper critical zone, Western Bushveld Complex, South Africa; Earth Plant. Sci. Lett. 74 58-68

Basu A R, Roy S L, Saha A K and Sarkar S N 19813800 million year old crust in eastern India and mantle differentiation; Science 212 1502-1506

Beamish D 1986 Deep crustal geoelectric structure beneath the Northumberland Basin; Geophy. J. Roy. Artr. Soc. 84 619-640

Beck A E and Sass J H 1966 A preliminary value of high heat flow at the Muskox intrusion near copper mine, N.W.J., Canada; Earth and Planet Science Letters 1 123-129

Cantwell T, Nelson P and Webb J 1965 Deep resistivity measurements in the pacific north west; Jour. of Geophys. Research V. 70(8) 1931-1937

Carte A E and Van Rooyen A I M 1969 Further measurements of heat flow in South Africa; Geol. Soc. South Africa Special Publication No. 2 (Upper Mantle Project) pp. 445-448 
Clifford F and Kennedy G C 1982 'Diamond' In (Ed. Sybil P Parker) McGraw-Hill Encyclopedia of Science and Technology 5th Edition pp. 162-166

Connerney J E P, Nekunt A and Kuekes A P 1980 Deep crustal electrical conductivity in the Adirondacks; Jour. Geophy. Research 85 2605-2614

Cox A and Hart R B, 1986 Plate Tectonics, how it works, Blackwell Scientific Publication Company

Datt R H and Batten R L 1988 Evolution of the earth, McGraw Hill Book Company

Depaolo D J 1983 Geochemical evolution of the crust and mantle; Reviews of Geophysics and Space Physics No 621 1347-1358

Drury M J and Hyndeman 1979 The electrical resistivity of oceanic basalts; Jour. Geophy. Res. 84 4537-4545

Duba A G and Shankland T J 1982 Free Carbon and electrical conductivity in the earth's mantle; Geoph. Res. Lett. 9 1271-1275

Fyfe W S, Prince W J and Thomson A B 1978 Fluids in the earth's crust. In developments in Geochemistry I, Elsevier, Amsterdam

Garland G D 1975 Correlation between electrical conductivity and other geophysical parameters; $P h y$. Earth Planet. Inter 10 220-230

Gass I G, Smith P J, Wilson R C L 1973 (Eds) Understanding the earth, (2nd edition), The Arthemis Press, Suesex

Ghosh S, Ray S L and Saha A K 1986 Petrochemistry and origin of the Manda-Asana-Besoi granite in the southeastern part of the Singhbhum granite batholith; Quartz. Jour. Geol. Min. Mat. Soc., Ind. No. 3 58 181-200

Haroi K I and Simmons G 1969 Spherical harmonic analysis of terrestrial heat flow; Earth Plant. Sci. Lett. 6 386-395

Haak V and Hutton R 1986 The nature of the lower continental crust, Geological Society Special Publication, No. 24 (eds) J B Carswell, D A Hall and Wedepol K H pp. 35-49

Hyndeman R D and Hyndeman D W 1968 Water saturation and high electrical conductivity in the lower continental crust; Earth Planet. Sci. Lett. 4 427-432

Jaeger J C 1970 Heat flow and radioactivity in Australia; Earth and Planet. Sci. Lett. $8285-292$

Jones A G 1982a Observations of the electrical asthenosphere beneath Scandinavia; Tectonophysics 90 37-55

Jones A G 1982b On the electrical crust-mantle structure in Fennoscandia: No Moho, and the asthenosphere revealed; Geophys. J.R. Astr. Soc. 68 371-388

Jones A G and Hutton R 1979 A multistation magnetotelluric study in Southern Scotland-I. Fieldwork, data analysis and results; Geophy. Jour. Roy. Astr. Soc. 56 329-349

Jiracek G R, Gustafson E P and Mitchell P S 1983 Magnetotelluric results opposing magma origin of crustal conductors in the Rio Granda rift; Tectonophysics 94 299-326

Kaufman A A and Keller G V 1981 The magnetotelluric sounding method, Elsevier, Amsterdam pp. 482

Keller G V, Anderson L A and Pritchard J I 1966 Geological Survey Investigations of the electrical properties of the crust and uppermantle; Geophysics 31 1078-1087

Kurtz R D 1982 Magnetotelluric interpretation of crustal and mantle structure in the Grenville Province; Geophy. Jour. Roy. Astr. Soc. 70 373-397

Kurtz R D and Garland G D 1976 Magnetotelluric measurements in Eastern Canada; Geophy. Jour. Roy. Astr. Soc. 45 321-347

Lachenbruch A H 1970 Crustal temperature and heat production: Implication of the linear heat flow reaction; Jour. Geophy. Res. 75 3291-3300

Lachenbruch A H and Bunker C M 1971 Vertical gradients of heat flow production in the continental crust. Some estimates from borehole data; J. Geophys. Res. $763832-3860$

Lee W H K and Uyeda S 1965 Review of heat flow data in terrestrial heat flow; American Geophysical Union Monograph No. 8 pp. 87-190

Mitchell K J and Landisman M 1971 Electrical and seismic properties of the earth's crust in the southwestern great plains in the U.S.A.; Geophysics, No. 236 363-381

Negi J G, Saraf B, Agrawal P K and Panday O P 1987 Large variation of Curie depth and lithosphere thickness beneath the Indian Subcontinent and a case for magnetothermometry; Geophy. Jour. Roy. Astr. Soc. $88763-775$

Olhoeft G R 1981 Electrical properties of granite with implications for the lower crust; Jour. Geophy. Res. 89 931-936

Olhoeft G R $1981 \mathrm{~b}$ Electrical properties of rocks in physical of properties of rocks and minerals (ed.) Y S Touloukian, W R Judd and R F Roy (New York: McGraw Hill) pp. 257-329

Pollack H N and Chapman D S 1977 On the regional variation of heat flow, geotherm and lithosphere thickness; Tectonophysics 38 279-296 
Polyak B G and Sminrov Y B 1968 Relationship between terrestrial heat flow and the tectonics of continents; Geotectonics 4 205-213

Rankin D and Pascal F 1985a The stability of results in the magnetotelluric method (Preprint, Unpublished)

Rankin D and Pascal F 1985b The North American crustal plains conductivity anomaly disappears at the Canada/U.S. border (unpublished preprint)

Rao R V M, Rao G V and Harinarayan 1976 Radioactive heat generation and heat flow in the Indian Shield; Earth Planet. Sci. Lett. 30 57-64

Ravi Shankar 1988 Heat flow map of India and discussions or its geological and economic significance; Indian Minerals No. $24289-110$

Saha A K, Ghosh S, Dasgupta D, Mukhopadhayay A K and Roy S L 1984 Studies on crustal evolution of the Singhbhum-Orissa Iron ore craton. Monograph on crustal evolution; Ind. Soc. Earth Sciences pp. $1-74$

Saha A K and Roy S L 1984a Early-middle Archaean Crustal evolution of the Singhbhum-Orissa craton; Ind. Jour. Earth Science, CEISM seminar volume pp. 1-18

Saha A K and Roy S L 1984b The structural and geochemical evolution of the singhbhum granite batholithic complex, India; Tectonophysics 105 163-176

Saha A K. Roy S L and Sarkar S N 1988 Early history of the earth; evidence from the eastern India shield. Precambrian of the Eastern Indian Shield. Mem. 8, (ed.) D. Mukhopadhaya; Geol. sec. of India, Bangalore

Saha A K, Sarkar S N and Roy S L 1986 Importance of multiple method dating in Precambrian geology: examples from Singhbhum-Orissa region, Eastern India. Indian Jour. of Earth Sci. No. 2-313 129-144

Sarkar S N and Saha A K 1959 A revised correlation of the iron ore series north and south of the copper belt thrust in Singhbhum and adjacent areas; Quart. Jour. Geol. Min. Met. Soc. India 31 129-132

Sass J H, Killen P C and Mustonan E D 1968 Heat flow and surface radioactivity in the Quirke Lake Syncline near Elliot Lake, Ontario, Canada; Can. Jour. Earth Sci. 5 1417-1425

Shankland T J and Anders M E 1983 Electrical Conductivity, temperature and fluids in the lower crust; Jour. Geophy. Res. No. B.11 $889475-9484$

Shankland T J and Waff H S 1977 Partial melting and electrical conductivity anomalies in the upper mantle. Jour. Geophy. Res. N. $33825409-5417$

Singh R N and Negi J G 1982 High Moho temperature in the Inviian Shield; Tectonophysics 82 229-306

Stanley W D, Boeh! J E, Bostick F X and Smith H W 1977 Geothermal significance of magnetotelluric sounding in the eastern snake river plain-yellowstone region; Jour. Geoph. Res. 82 2501-2514

Sternberg B K 1979 Electrical resistivity structure of the crust in the southern extension of the Canadian Shield-layered earth models; Jour. Geophy. Res. $84212-228$

Sternberg B K and Clay C S 1977 Flambean anomaly: A high conductivity anomaly in the southern extension of the Canadian shield, in the earth's crust: Its nature and physical properties (ed.) J G Heacock, Geoony. Monograpk Soc. Vol 20, pp. 501-530, AGU, Washington, D.C.

Stesky R M and Brace W F 1973 Electrical Conductivity of serpentinised rocks to 6 kilobars; Jour. Gecphy. Res. 78 7614-7621

Swift C M Jr 1969 A magnetotelluric investigation of an electrical conductivity anomaly in the south western United States, Ph.D. thesis, M.I.T.

Turner F J and Verhoogen J 1951 Igneous and Metamorphic Petrology, McGraw Hill, New York, Toranto, London

Vanzijl J S N 1978 The relationship between the deep electrical resistivity structure and tectonic provinces in Southern Africa Part 1. Results obtained by Schlumberger Soundings; Trans. Geol. Soc. S. Afr. 81 $129-142$

Verma R K, Rao R V M and Gupta M L 1966 Terrestrial heat flow in Mosabani Mine, Singhbhum Dist., Bihar, India; Jour. Geophy. Res. 714943

Verma R K, Sarma A U S and Mukhopadhyay M 1984 Gravity field over Singhbhum, its relationship to geology and tectonic history: Tectonophysics 106 87-107

Vozoff K 1972 The magnetotelluric method in the exploration of sedimentary basins; Geophysics No. 1 37 98-141

Windely B F 1977 The evoluing continents, Wiley, Londion

Woermann E and Rosenhauer M Gottingen 1985 Fluid Phases and the redox state of the earth's mantle. Extrapolations based on experimental, phase-theoretical and petrological data; Fort schritte der Mineralogie $63263-349$

Wyllie P J 1971 Experimental limits for melting in the earth's crust and upper mantle; Geophys. Monograph. Am. Geophy: Union 14 279-301

Wyllie P J 1977 crustal Anatexis: An experimental review: Tectonophysics 43 41-71 